\title{
Effects of Exhaust Gas Hydrogen Addition and Oxygenated Fuel Blends on the Light-Off Performance of a Three-Way Catalyst
}

\author{
Viktor Kärcher, Paul Hellier, Nicos Ladommatos \\ University College London
}

\begin{abstract}
A significant amount of harmful emissions pass unreacted through catalytic after-treatment devices for IC engines before the light-off temperature is reached, despite the high conversion efficiency of these systems in fully warm conditions. Further tightening of fleet targets and worldwide emission regulations will make a faster catalyst light-off to meet legislated standards hence reduce the impact of road transport on air quality even more critical.
\end{abstract}

This work investigates the effect of adding hydrogen $\left(\mathrm{H}_{2}\right)$ at levels up to $2500 \mathrm{ppm}$ into the exhaust gases produced by combustion of various oxygenated $\mathrm{C}_{2-}$, $\mathrm{C}_{4-}$ and renewable fuel molecules blended at $20 \%$ wt/wt with gasoline on the light-off performance of a commercially available three-way catalyst (TWC) $(0.61$ $\mathrm{L}, \mathrm{Pd} / \mathrm{Rh} / \mathrm{Pt}-19 / 5 / 1,15 \mathrm{~g}$ ). The study was conducted on a modified naturally aspirated, $1.4 \mathrm{~L}$, four-cylinder, direct-injected, spark-ignition engine. The experiments were performed at the steady-state condition of 1600 $\mathrm{r} / \mathrm{min}$ and BMEP of $3.6 \mathrm{bar}$, derived from a time-based load distribution of a WLTC cycle simulation, with levels of gaseous pollutants, particulate matter and hydrogen measured both upstream and downstream of the TWC.

Low-level $\mathrm{H}_{2}$ addition reduced the TWC light-off temperature of $\mathrm{CO}, \mathrm{THC}$ and $\mathrm{NO}_{\mathrm{x}}$, and decreased the time to reach steady particulate number/ mass levels post-TWC. The presence of $\mathrm{C}_{2}-$ (ethanol, acetaldehyde, diethyl ether) and $\mathrm{C}_{4^{-}}$(1-butanol, butyraldehyde, 2-butanone, methyl tert-butyl ether) molecules displayed minimal impact on the conversion efficiencies relative to operating the engine with pure reference gasoline. Linalool and $\mathrm{y}$-valerolactone blends displayed a slight increase in light-off temperature and produced elevated levels of particulates pre and post catalyst, while 2-methylfuran and 2-methyltetrahydrofuran blends emitted lower levels of particulates. Hydrogen levels post-converter were found to reach almost full conversion after $\mathrm{H}_{2}$ light-off, independent of the amount added, however after $\mathrm{CO}$ light-off the conversion of the additional $\mathrm{H}_{2}$ was reduced significantly.

\section{INTRODUCTION}

Further improvements in combustion processes, alternative fuel compositions and after-treatment devices are necessary to address the issues of global climate change and local air quality to limit the negative impacts arising on public health, especially in densely populated cities. Continuously reducing levels of legislated pollutants in the USA and Europe have driven the development of highly efficient aftertreatment devices for many years [1], [2]. State-of-theart TWC's reach conversion efficiencies significantly above $90 \%$ for all legislated gaseous species in warmed-up running conditions and the majority of cumulative tailpipe emissions in legislated cycles are emitted before the light-off temperature of the converter is reached [3], [4]. The announced thresholds for $\mathrm{CO}_{2}$ fleet emissions in 2020 in Europe, strict legislation introduced in China and India and an anticipated further reduction in solid and gaseous emissions levels with post Euro 6 regulations [2], [5], make further improvement of after-treatment devices, and the search for alternative sustainable fuel sources, inevitable.

The addition of $\mathrm{H}_{2}$ either during combustion or to exhaust gases has been significantly researched in an automotive context as a means to reduce pollutant emissions. Catalytic on-board reformers, operated with additional fuel injection or engine produced rich exhaust gas, have been proposed as a potential way to generate $\mathrm{H}_{2}$ enriched gas which can be used in exhaust gas recirculation to improve engine efficiency or added to the exhaust to enhance the catalytic performance of after-treatment systems [6]-[10]. Approaches to the on-board storage of hydrogen have included the use of different hydrides, amides and imides used as solid-state hydrogen storage materials [11], which would allow hydrogen to be stored and released in a less extreme environment than in currently used high pressure compressed gas storage vessels. Heimrich and Andrews [12] investigated an on-board electrolyser and storage unit for hydrogen which allowed $\mathrm{H}_{2}$ in combination with secondary air to be injected upstream of a TWC to improve the light-off performance. For the weighted emissions over the 
FTP cycle, the system showed a distinct improvement of cumulative $\mathrm{CO}$ and THC levels over a Pt-only catalyst, however, due to the additional load of the electrolyser, a negative effect on NOx emissions and fuel consumption was observed. Other approaches to reduce cold-start engine-out emissions have been investigated and used for a stoichiometric operated engine with a TWC, for example, electrical heating or secondary air/fuel injection, however, all the mentioned approaches result in an overall reduction of the efficiency due to the necessary energy to drive the system or additional fuel injection. Meanwhile, the addition of pure hydrogen into the exhaust stream to increase the cold-start efficiency of different aftertreatment devices has been a highly researched topic for different catalytic reactions operated in oxygen-rich environments. Several studies have observed a reaction promoting "Hydrogen effect", not directly attributable to the level of heat release from $\mathrm{H}_{2}$ oxidation and with promoting effects in converting the legislated species carbon monoxide [13], hydrocarbons [14] and nitrogen oxides [15]. Enhancements in the regeneration of particulate filters and other commercial after-treatment systems have also been observed with the addition of $\mathrm{H}_{2}$ [16], [17].

Salomons et al. [13], [18] investigated the " $\mathrm{H}_{2}$-effect" on $\mathrm{CO}$ oxidation in a pure gas environment $\left(6 \mathrm{vol} \% \mathrm{O}_{2}\right.$, varying levels of $\mathrm{CO}, \mathrm{H}_{2}$ ) over a $\mathrm{Pt} / \mathrm{Al}_{2} \mathrm{O}_{3}$ catalyst and discovered a $22{ }^{\circ} \mathrm{C}$ decrease in light-off temperature when adding $500 \mathrm{ppm}$ of hydrogen. Similar results were observed over a $\mathrm{Pt} / \mathrm{Pd}$ alumina catalyst in lean diesel exhaust, where an $\mathrm{H}_{2}$ addition of $1000 \mathrm{ppm}$ decreased the light-off temperature by $30^{\circ} \mathrm{C}$, with a temperature increase along the catalyst of just $3^{\circ} \mathrm{C}$, which could not solely account for the improvement at low hydrogen levels, suggesting a combined effect of hydrogen-containing intermediate species and the thermal benefit [14]; this contradicted results which implicated only heat release from hydrogen oxidation in reducing light-off temperatures [19]. Burch \& Coleman [20], [21] conducted research on the effect of hydrogen in $\mathrm{NO}_{x}$ reduction reactions over a variety of washcoat and support materials, with a $\mathrm{Pt} / 10 \mathrm{Mo} / 0.27 \mathrm{Na} / \mathrm{Al}_{2} \mathrm{O}_{3}$ coated catalyst in oxygen-rich exhaust gas displaying the best performance and raising the selectivity for $\mathrm{N}_{2}$ production at $120^{\circ} \mathrm{C}$ from $20 \%$ to $50 \%$ with the addition of 4000 ppm hydrogen [21]. $\mathrm{H}_{2}$ also increased the performance of $\mathrm{NO}_{x}$ reduction by propane, improving the conversion efficiency to almost $60 \%$ at $450{ }^{\circ} \mathrm{C}$ and also reducing the initiation temperature of the reaction to less than $325^{\circ} \mathrm{C}[22]$.

Concurrent to legislative limits and technology innovation to reduce the emission of pollutants impacting on local air quality, has been the increasing utilisation of renewable fuels in road transport. To deliver the aims of the "Clean Energy for All Europeans package" legislative framework, the European Parliament recently raised its target for Renewable Energy Sources (RES) until 2030 even further, from an initially proposed $27 \%$ to at least $32 \%$ to limit $\mathrm{CO}_{2}$ output [23]. The November 2018 adopted Renewable Energy Directive II (RED II), in comparison to the initial proposal, additionally sets a minimum threshold of $14 \%$ for energy consumed in the road and rail transport sector to originate from renewable sources [24]. Specific greenhouse gas (GHG) and sustainability criteria for biofuels, as well as a cap on $1^{\text {st }}$ generation biofuels, were implemented to be creditable towards the overall RES target and incentives for advanced biofuels derived from sustainable feedstocks were introduced, for example, algae, bagasse and household bio-waste [24].

Leitner et al. [25] addressed the issue of the likely great variety of possible advanced biofuel molecules from a diverse range of potential feedstocks, with lignocellulose biomass identified as one of the most abundant resources for the production of advanced biofuels and oxygenated fuel molecules [25]-[28]. A retrosynthetic approach was suggested to help identify viable fuel molecules through their effect on combustion behaviour and emissions formation, and subsequently find possible sources, intermediate platform molecules and sustainable production processes. The five- and six-carbon sugars incorporated in the cellulose and hemicellulose part of lignocellulose biomass could be converted to possible oxygenated fuel additives, based on different platform molecules like 5-hydroxymethyl-2-furaldehyde (HMF) and furfural [25]. Any potential fuel molecule used in a gasoline blend would need to fulfil specific legislated criteria to be usable in the established fuel infrastructure and meet emission regulations, or even improve tailpipe pollutant levels, and should not affect the lifetime and efficiency of the after-treatment system [29]. Ethanol and butanol [30] have been the most widely considered oxygenated biofuels, while ethers, primarily MTBE [31], have been investigated and utilised as knock improvers. Ethanol blends up to 30 vol\%, performing a hot ECE cycle, showed decreasing tailpipe emission trends downstream of a TWC for CO, $\mathrm{HC}$ and $\mathrm{NO}_{x}$ levels with increasing oxygen levels in the fuel blends, in comparison to oxygen free baseline gasoline. Butanol-diesel blends (20 vol\%) significantly decreased light-off temperatures for $\mathrm{CO}$ and total hydrocarbon oxidation over a $\mathrm{Pt} / \mathrm{Pd}$-doped diesel oxidation catalyst (DOC) [32], [33], tentatively suggested to be due to the presence of butanol and its derivatives in the exhaust stream leading to a rise in reactivity and diffusivity resulting in earlier light-off.

The objective of this study was to examine potential benefits on light-off temperature and conversion efficiency of low-level $\mathrm{H}_{2}$ addition upstream of a TWC, which has been observed previously in oxygen-rich exhaust environments. Furthermore, looking ahead to the increasing use of renewable fuel blends, consisting of various oxygenated molecules blended in gasoline, the effect of these blends on TWC light-off behaviour and potential synergies between the effectiveness of $\mathrm{H}_{2}$ addition and the exhaust gases produced by oxygenated fuel blends were investigated; an effect similarly reported in a diesel after-treatment context [34]. This paper, therefore, presents the light-off results of a commercially available TWC installed on a modified DI-SI-engine, undertaken with simultaneous emission measurements pre-/ post-converter and consecutive tests for hydrogen and particulate emissions (with $\mathrm{H}_{2}$ supplied from a high-pressure cylinder rather than employing a specific on-board hydrogen storage or production system). Different low- 
levels of hydrogen were added into the exhaust flow upstream of the catalytic converter, with the engine operating conditions based on a single speed and load point derived from a simulated WLTC cycle. The effect of $\mathrm{H}_{2}$, as well as eleven potential oxygenated biofuels blended with reference gasoline (20\%wt/wt) and possible synergistic effects with $\mathrm{H}_{2}$ on the TWC lightoff performance, were examined.

\section{EXPERIMENTAL SETUP}

\section{ENGINE SETUP}

The experiments were conducted on a naturally aspirated Volkswagen, 4-cylinder, 1.4 litres, directinjection, spark-ignition engine. The engine was modified to operate in a three or a one plus threecylinder configuration with individual control of parameters including throttle position, spark-timing and fuel pressure for the bank of three cylinders relative to the single cylinder, enabling single cylinder experiments on the front cylinder, as well as emission experiments on the separated back three cylinders. The main specifications of the engine are summarised in Table 1.

Table 1: Engine specifications

\begin{tabular}{|ll|}
\hline Number of cylinders & 4 \\
Bore $x$ stroke & $76.5 \times 75.6 \mathrm{~mm}$ \\
Swept volume/cylinder & $347.5 \mathrm{~cm}^{3}$ \\
Compression ratio & $10: 1$ \\
Valves per cylinder & 4 \\
Fuel injection pump & 3-lobe, cam-driven piston \\
& pump \\
DI fuel injectors & Magneti Marelli, 6-hole \\
Coolant temperature & $82 \pm 4{ }^{\circ} \mathrm{C}$ \\
Oil temperature & $80 \pm 2{ }^{\circ} \mathrm{C}$ \\
\hline
\end{tabular}

The airflow was measured with a Romet G65 positive displacement volumetric air-flow meter with pressure and temperature measured at the inlet of the air flow meter. A 60-litre expansion tank and a manual twoinch three-way valve were placed between the engine inlet and the flow meter to minimise pulsation in the airflow and to split the measured airflow according to the particular engine setup. The manifold pressure was obtained with a piezo-resistive pressure transducer (Druck PTX7517, range 0-1 bar absolute) with an accuracy of $\pm 0.2 \%$. The engine was equipped with two water-cooled, piezo-electric pressure transducers (Kistler 6061B) to measure the in-cylinder gas pressure, connected to Kistler charge amplifiers (model: 5015 and 5018) and pegged to the intake manifold pressure. The in-cylinder pressure and other combustion-related values were logged to a resolution of 0.5 CAD with a Leine \& Linde RSI 503 shaft encoder. An in-house developed National Instruments LabView program was utilised to record data and perform online data analysis for values including indicated mean effective pressure (IMEP) and net heat release rate (HRR).
The engine was operated via a fully accessible, mapbased Engine Control Unit (ECU) F88GDI4, acquired from LifeRacing Ltd. The system included a closedloop (CL) lambda capability to operate the engine within a tight range of the set lambda value. The lambda sensor in the CL circuit was an NGK wideband oxygen sensor. The low-pressure side of the fuel system was fed by a nitrogen pressurised fuel tank at 4 bar. The fuel consumption measurement was performed by a Bronkhorst Coriolis mass flow-meter (mini cori-flow M14), which also incorporated fuel temperature and fuel density measurements. The high-pressure part of the fuel system was actuated by a three-lobe, cam-driven high-pressure fuel pump, which had an adjustable injection pressure range of up to 150 bar and injected directly into the engine combustion chamber via commercial six-hole solenoid injectors. The main parameters of the reference gasoline (RGL) utilised are displayed in Table 2.

Table 2: Reference gasoline properties

\begin{tabular}{|lc|}
\hline Density at $20{ }^{\circ} \mathrm{C}, \mathrm{kg} / \mathrm{m}^{3}$ & 747.3 \\
Initial boiling point, ${ }^{\circ} \mathrm{C}$ & 33.8 \\
$\%$ Evaporated at $70{ }^{\circ} \mathrm{C}$, vol\% & 29.5 \\
$\%$ Evaporated at $100{ }^{\circ} \mathrm{C}$, vol\% & 51.4 \\
Final boiling point, ${ }^{\circ} \mathrm{C}$ & 201.9 \\
Carbon content, wt $\%$ & 86.49 \\
Hydrogen content, wt\% & 12.54 \\
Oxygen content, wt\% & 0.97 \\
Aromatics, vol\% & 30.8 \\
Olefins, vol\% & 0.3 \\
Saturates, vol\% & 63.5 \\
Lower heating value, MJ/kg & 42.7 \\
Motor octane number & 87.5 \\
Research octane number & 95.8 \\
\hline
\end{tabular}

Various monitoring and control temperatures were measured with $1 \mathrm{~mm} \varnothing \mathrm{K}$-type thermocouples with each signal amplified with an Adafruit AD8495 K-type analogue thermocouple amplifier for reduced signal interference. Figure 1 shows a schematic overview of the overall experimental setup.

\section{CATALYTIC CONVERTER SETUP}

The catalytic converter was placed roughly $500 \mathrm{~mm}$ downstream of the exhaust valves as shown in Figure 1. Temperature measurements were recorded before, at three positions throughout, and after the catalytic device. The thermocouples inside the converter were placed at $25 \%, 50 \%$ and $75 \%$ of the total brick length, positioned perpendicular to the converter surface facing the exhaust stream, with a penetration of $25 \%$, $37.5 \%$ and $50 \%$ of the brick diameter and an angular offset of 20 degrees with each thermocouple, though an even radial heat distribution throughout the converter was expected. Online exhaust flow calculations were performed on the basis of the measured air flow and the specific calculated stoichiometric air-to-fuel ratio (AFR) to determine the real-time space velocity through the converter. Additionally, two Bosch wideband lambda sensors (LSU ADV), pre- and post-exhaust, were installed to 
measure the mixture stoichiometry of the exhaust gas. The heating and signal processing of the lambda sensors was carried out by two wideband ALM-LED controllers supplied by Ecotrons LLC. The devices included signal processing, as well as AFR adjustment for compatibility with different fuel blends.

Throughout this work, $\mathrm{H}_{2}$ was supplied from a compressed hydrogen gas bottle and introduced into the exhaust flow roughly $100 \mathrm{~mm}$ before the converter to avoid any hydrogen oxidation before reaching the catalytic surface. The hydrogen inlet point was placed after the pre-catalytic lambda measurement to prevent any signal interference with the lambda signal, which has been reported in previous studies [35], [36]. The calculated exhaust flow was used for an automated hydrogen set-point adjustment throughout the light-off experiment, executed by a Bronkhorst thermal mass flow controller (F-201CV-10K) with a flow range of up to 13 litres/minute, so as to provide constant levels of $\mathrm{H}_{2}$ addition during engine warm-up.
The gaseous exhaust emissions were transferred via heated lines and simultaneously analysed with two exhaust Horiba MEXA-9100 series analyser racks. CO $( \pm 0.01 \%)$ and $\mathrm{CO}_{2}( \pm 0.01 \%)$ were measured with a non-dispersive infrared absorption analyser, $\mathrm{NO}_{x}$ via a chemiluminescence analyser ( $\pm 1 \mathrm{ppm})$, a flame ionisation detector for THC ( $\pm 10 \mathrm{ppm}$ ) emissions and $\mathrm{O}_{2}$ concentration through a magneto-pneumatic analyser $( \pm 0.1 \%)$. The particulate number and size distribution in the exhaust was measured with a differential mobility spectrometer (Cambustion DMS500) and the hydrogen levels with an HSense mass spectrometer (V\&F Analyse- und Messtechnik $\mathrm{GmbH}$ ). All emission samples were taken in a range of 100-200 mm before and after the catalytic converter. The hydrogen and particulate data shown were recorded in consecutive tests and not simultaneously due to analyser availability.

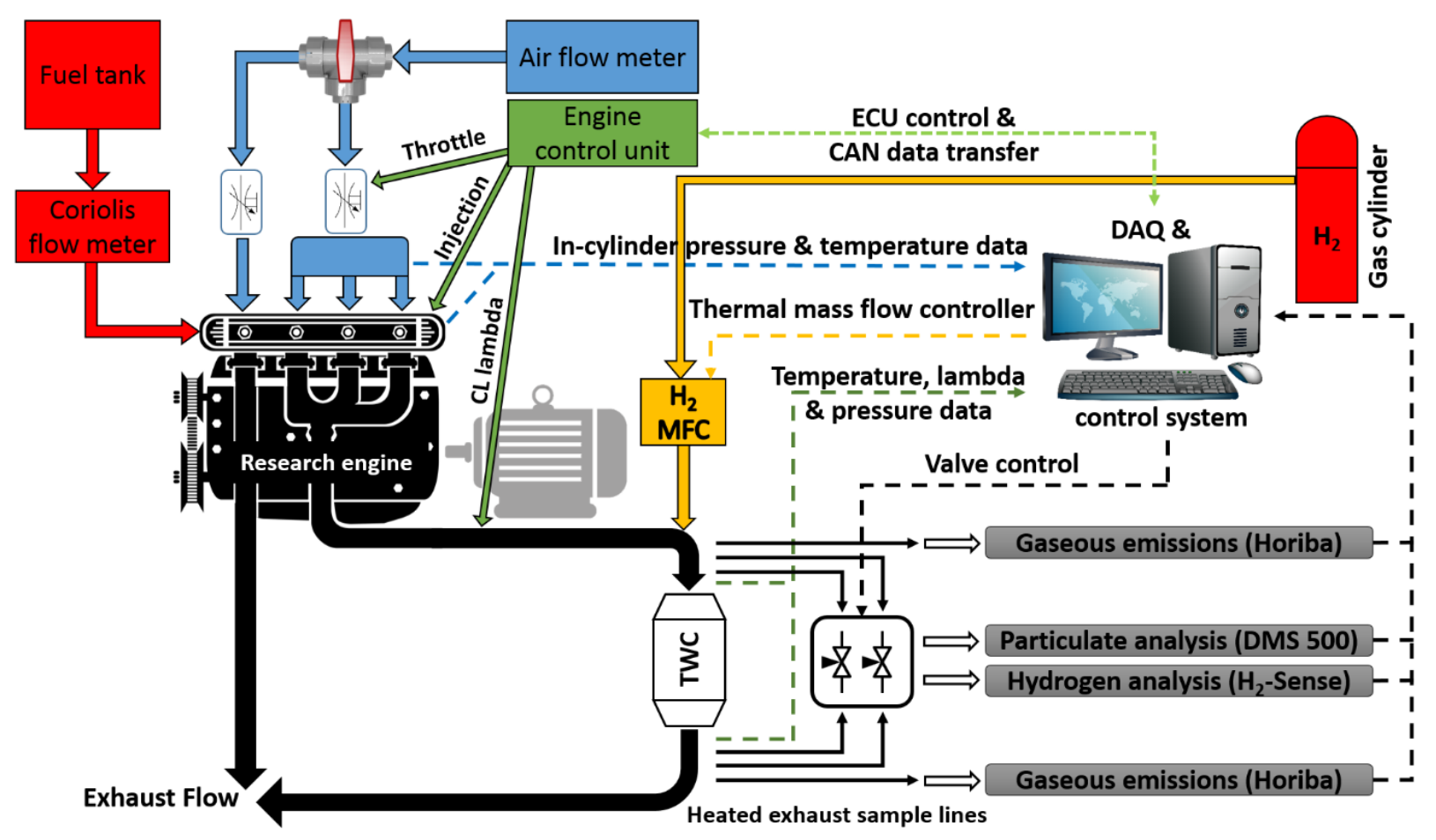

Figure 1: Schematic overview of the experimental setup

\section{EXPERIMENTAL METHODOLOGY}

For the experiments described in this paper, hydrogen was introduced into the system at levels between 500 - $2500 \mathrm{ppm}$, covering a similar range of hydrogen levels found to be effective in previous work [7], [13], [14]. The commercially available TWC used for all tests described in this work was coated for Euro VI legislation. The 0.61 -litre ceramic brick used three platinum group metals $\mathrm{Pd} / \mathrm{Rh} / \mathrm{Pt}$ in the washcoat with a loading of $15 \mathrm{~g}$. The available data for the ceramic TWC brick is summarised in Table 3 .
Table 3: Properties of the ceramic TWC brick

\begin{tabular}{|lc|}
\hline Catalyst type & 3-way $-\mathrm{Pd} / \mathrm{Rh} / \mathrm{Pt}$ \\
Base material & cordierite \\
PGM ratio & $19 / 5 / 1$ \\
PGM loading & $15 \mathrm{~g}$ \\
$\varnothing$ of element & $101 \mathrm{~mm}$ \\
Length of element & $76 \mathrm{~mm}$ \\
Volume & $0.61 \mathrm{~L}$ \\
Cell density & $400 \mathrm{cpsi}$ \\
Wall thickness & $\sim 0.15 \mathrm{~mm}$ \\
\hline
\end{tabular}




\section{FUELS INVESTIGATED}

The selected fuels (and the in-text abbreviations referred to for each throughout this paper) are summarised in Table 4. The assay of all molecules used was $\geq 99 \%$, except for butyraldehyde and linalool with assay values of $\geq 96 \%$ and $\geq 97 \%$ respectively. The fuels were divided into three groups, $\mathrm{C}_{2}$-chain, $\mathrm{C}_{4}$ chain and renewable molecules. The $\mathrm{C}_{2}$ - and $\mathrm{C}_{4}$-series were selected so as to observe the effect of different carbon to oxygen bond types within a molecule while keeping the overall carbon number constant. For the completion of the logical $\mathrm{C}_{2}$-chain group, dimethyl ether (DME) was replaced by diethyl ether due to the very low boiling point of the former and it being in the gas phase at ambient conditions. Four additional oxygenated fuel molecules potentially derived from renewable feedstock sources were also included in the test series. Each test molecule was blended with RGL at a $20 \%$ by mass ratio to allow precise element ratio calculations for each blend. The blending amount of $20 \% \mathrm{wt} / \mathrm{wt}$ was chosen as a potential target for future blending levels in European legislation to meet $\mathrm{CO}_{2}$ output targets set in RED II, and also considered in the Horizon 2020 work program with a possible start of standardisation procedures for E20/E25 ethanol blends [37]-[39]. However, it should be noted that in countries like Brazil much higher levels are already commonly used, and future changes in European blending targets might differ from the chosen limit in this study.

Table 4: Specifications of fuel blend molecules

\begin{tabular}{|c|c|c|c|c|c|c|c|c|c|}
\hline & Fuel & $\begin{array}{c}\text { In-text } \\
\text { use }\end{array}$ & Formula & Structure & $\begin{array}{l}\text { AFR } \\
\text { stoich }\end{array}$ & $\begin{array}{l}\mathrm{H} / \mathrm{C} \\
\text { ratio }\end{array}$ & $\begin{array}{c}\text { Oxygen } \\
{[\%]}\end{array}$ & $\begin{array}{c}\text { Mass } \\
{[\mathrm{g} / \mathrm{mol}]}\end{array}$ & $\begin{array}{c}\text { Density } \\
{\left[\mathrm{kg} / \mathrm{m}^{3}\right]}\end{array}$ \\
\hline \multirow{3}{*}{$\mathfrak{c}$} & Ethanol & ETH & $\mathrm{C}_{2} \mathrm{H}_{6} \mathrm{O}$ & & 9.0 & 3.0 & 34.7 & 46.1 & 789 \\
\hline & Acetaldehyde & ACA & $\mathrm{C}_{2} \mathrm{H}_{4} \mathrm{O}$ & & 7.8 & 2.0 & 36.3 & 44.0 & 783 \\
\hline & Diethyl ether & DEE & $\mathrm{C}_{4} \mathrm{H}_{10} \mathrm{O}$ & & 11.2 & 2.5 & 21.6 & 74.1 & 713 \\
\hline \multirow{4}{*}{ U } & 1-Butanol & BTN & $\mathrm{C}_{4} \mathrm{H}_{10} \mathrm{O}$ & & 11.2 & 2.5 & 21.6 & 74.1 & 810 \\
\hline & Butyraldehyde & BTA & $\mathrm{C}_{4} \mathrm{H}_{8} \mathrm{O}$ & & 10.5 & 2.0 & 22.2 & 72.1 & 802 \\
\hline & 2-Butanone & BUO & $\mathrm{C}_{4} \mathrm{H}_{8} \mathrm{O}$ & & 10.5 & 2.0 & 22.2 & 72.1 & 805 \\
\hline & Methyl tert-butyl ether & MTBE & $\mathrm{C}_{5} \mathrm{H}_{12} \mathrm{O}$ & & 11.8 & 2.4 & 18.1 & 88.2 & 742 \\
\hline \multirow{4}{*}{$\begin{array}{l}\frac{0}{0} \\
\frac{0}{0} \\
\frac{0}{0} \\
\frac{5}{0} \\
\simeq\end{array}$} & 2-methylfuran & MF & $\mathrm{C}_{5} \mathrm{H}_{6} \mathrm{O}$ & & 10.1 & 1.2 & 19.5 & 82.1 & 916 \\
\hline & 2-methyltetrahydrofuran & MTHF & $\mathrm{C}_{5} \mathrm{H}_{10} \mathrm{O}$ & & 11.2 & 2.0 & 18.6 & 86.1 & 854 \\
\hline & $\mathrm{v}$-valerolactone & GVL & $\mathrm{C}_{5} \mathrm{H}_{8} \mathrm{O}_{2}$ & & 8.3 & 1.6 & 32.0 & 100.1 & 1050 \\
\hline & Linalool & LNL & $\mathrm{C}_{10} \mathrm{H}_{18} \mathrm{O}$ & & 12.6 & 1.6 & 10.4 & 154.3 & 862 \\
\hline
\end{tabular}

\section{TEST PROCEDURE}

Throughout the current study, the engine was first warmed up to the oil and coolant values stated in Table 2 and with all three thermocouples situated inside the catalytic brick reading below $30^{\circ} \mathrm{C}$ prior to starting a test. The idling condition after engine start was set to $900 \mathrm{r} / \mathrm{min}$ for 12 seconds to stabilise, which represents the condition used in the WLTC cycle starting procedure [40]. These 12 seconds were also used for the heating up process of the $\mathrm{CL}$ lambda probe, which was not possible beforehand due to ECU safety measures which prevented this without the detection of a speed signal. Therefore, the engine was operated in an open-loop mode for this period. Subsequent to this stabilisation, the flow of hydrogen was started where applicable concurrent with the engine being accelerated to its final operating steady-state condition of $1600 \mathrm{r} / \mathrm{min}$ and $3.6 \mathrm{bar}$ BMEP, which was held for a total test time of 600 seconds. The speed/load condition was derived from a simulated WLTC cycle with a similar powered VW SI-DI-engine. Figure 2 shows the time-based load distribution plot over the 1800 seconds of the WLTC cycle. It displays the amount of time the engine spent within a range of speed and load conditions. On the basis of the simulation, the weighted distribution for all points up $2400 \mathrm{r} / \mathrm{min}$ was calculated, which resulted in the final test condition. The engine was operated for all tests at a spark timing of $15^{\circ} \mathrm{BTDC}$, an injection pressure of 80 bar, an injection timing of $280^{\circ} \mathrm{BTDC}$ and a CL lambda value of 0.995 , with an oscillation of $2.5 \%$ at 1 $\mathrm{Hz}$ (according to Hagelüken [1] a commonly used value in the automotive industry).

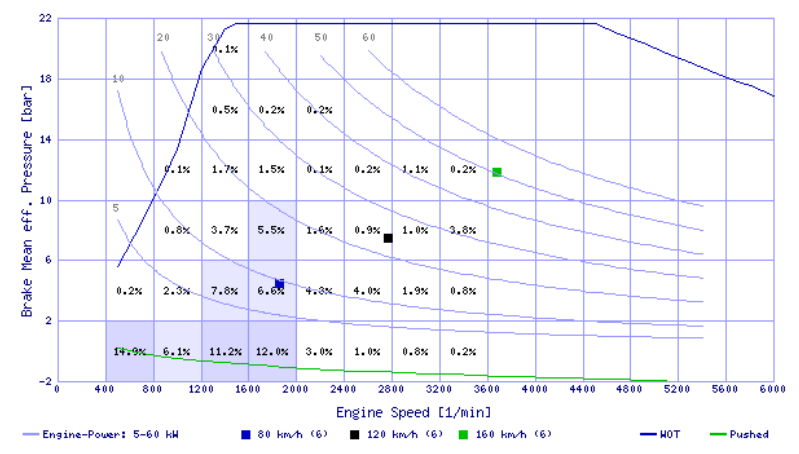

Figure 2: Time based load-speed distribution - WLTC [41] 
During this start-up engine procedure, the light-off profiles for all gaseous species, particulate emissions and temperatures were recorded. Throughout this work, the light-off temperature for all of the species reported was defined as the temperature at which $50 \%$ of the engine-out levels of that species had been converted. The first 300 seconds of the test could be considered the light-off part of the test, after which the temperatures and emissions had reached steady-state conditions.

\section{RESULTS AND DISCUSSION}

\section{TEMPERATURE PROFILES}

Figure 3 shows the temperature upstream of the TWC converter and a mean temperature value of the three in-brick temperature probes for the first 250 seconds after engine start for the different levels of $\mathrm{H}_{2}$ addition.

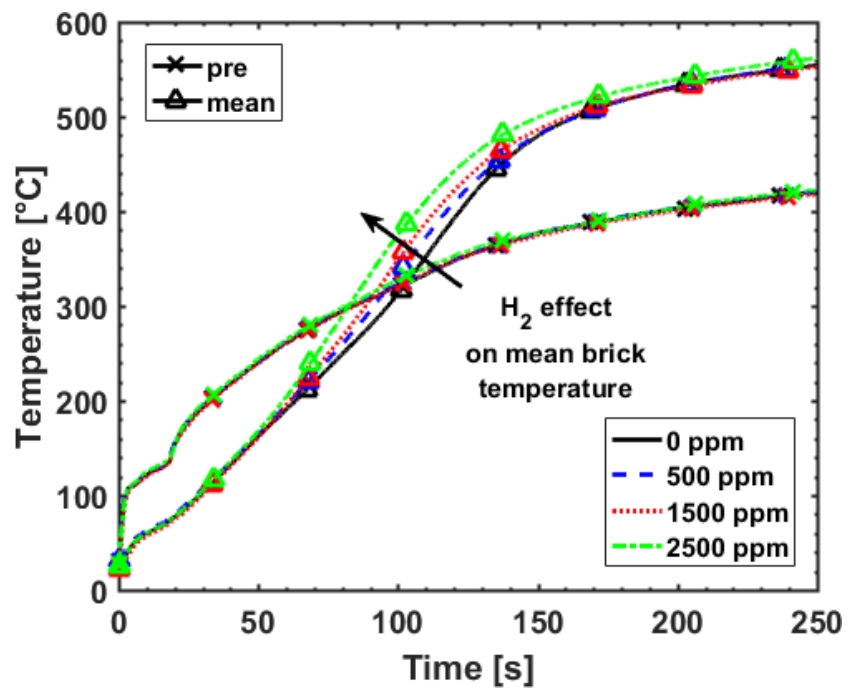

Figure 3: Pre-TWC and mean brick temperature profiles for different levels of $\mathrm{H}_{2}$ addition

The pre-catalyst temperatures shown in Figure 3 for all tests fall almost identically on top of each other, which represents the repeatability of the engine start-up process and therefore comparable temperature conditions upstream of the converter. The mean brick temperature shows clearly the effect of increasing levels of hydrogen on the temperature profile inside the brick; however, the exact position of the reaction is not visible. The individual brick temperatures showed a distinctly faster temperature increase in the first half of the brick suggesting that the majority of conversion reactions are taking place in the front part of the catalytic brick. The addition of $500 \mathrm{ppm}, 1500 \mathrm{ppm}$ and $2500 \mathrm{ppm}$ of hydrogen resulted in a mean temperature increase of $21^{\circ} \mathrm{C}, 36^{\circ} \mathrm{C}$ and $62{ }^{\circ} \mathrm{C}$ after 100 seconds of engine run time and a time decrease of $5 \mathrm{~s}, 8 \mathrm{~s}$ and $14 \mathrm{~s}$ to reach $300^{\circ} \mathrm{C}$ respectively. The almost identical increase with various $\mathrm{H}_{2}$ addition levels of the mean temperature for approximately the first $50 \mathrm{~s}$ after engine start, and up to $200{ }^{\circ} \mathrm{C}$, and the divergence afterwards, for the different $\mathrm{H}_{2}$ levels relative to $0 \mathrm{ppm}$ $\mathrm{H}_{2}$, indicates the exothermic energy produced by $\mathrm{H}_{2}$ oxidation.

\section{GASEOUS EMISSIONS}

Figure 4 a-d shows the change in conversion efficiency across the TWC of $\mathrm{CO}, \mathrm{THC}, \mathrm{NO}_{x}$ and $\mathrm{O}_{2}$ against converter inlet temperature, as well as the hydrogen levels (Figure $4 \mathrm{e}$ ) pre- and post-TWC and the preTWC temperature for the first $400 \mathrm{~s}$ after engine start. Hydrogen levels are presented as absolute values due to consecutive up- and downstream measurements. Figure 4 a-e exemplifies the effects of $\mathrm{H}_{2}$ addition on the light-off performance with RGL only, but similar trends were observed when the engine was operated with oxygenated fuel blends.

Figure 4a displays a decrease of light-off temperature for carbon monoxide oxidation for all levels of hydrogen added. However, the extent of this beneficial temperature effect, relative to the baseline of RGL and $0 \mathrm{ppm} \mathrm{H}_{2}$, decreased with higher amounts of $\mathrm{H}_{2}$ introduced, even though the mean temperature of the brick increased continuously with increasing levels of $\mathrm{H}_{2}$ added (Figure 3). The addition of $2500 \mathrm{ppm} \mathrm{H}_{2}$ resulted in a reduction in light-off temperature of $14{ }^{\circ} \mathrm{C}$ and $13 \mathrm{~s}$ in light-off time, a decrease $3{ }^{\circ} \mathrm{C}$ and $5 \mathrm{~s}$ greater than observed with the addition of $1500 \mathrm{ppm}$ $\mathrm{H}_{2}$. Similar effects of $\mathrm{H}_{2}$ addition can be observed for the hydrocarbon oxidation light-off temperature (Figure $4 \mathrm{~b}$ ). The addition of $500 \mathrm{ppm}$ resulted in a decreased catalyst inlet temperature and time of $6{ }^{\circ} \mathrm{C}$ and $6 \mathrm{~s}$ for a conversion rate of $50 \%$; however, the introduction of higher levels of $\mathrm{H}_{2}$ (1500 ppm \& 2500 ppm) did not show any beneficial effect or became counterproductive. The addition of $2500 \mathrm{ppm}$ of $\mathrm{H}_{2}$ resulted in a significantly decreased gradient of the light-off temperature slope for THC oxidation, despite an increase in low-temperature conversion efficiency at $315{ }^{\circ} \mathrm{C}$ from $6 \%$ to $16 \%$, such that the maximum conversion efficiency reached reduced to below $80 \%$ from $95 \%$ without $\mathrm{H}_{2}$ addition. In fact, a decrease in the maximum conversion efficiency achieved for both oxidation reactions (Figure $4 \mathrm{a}$ and $\mathrm{b}$ ) can be seen with $\mathrm{H}_{2}$ levels of $1500 \mathrm{ppm}$ and $2500 \mathrm{ppm}$.

Figure 4 c shows, conversely, an almost linear reduction in light-off temperature for nitrogen oxide conversion with increasing levels of $\mathrm{H}_{2}$ addition. Furthermore, it can be seen in Figure $4 \mathrm{c}$ that $\mathrm{H}_{2}$ improved the low-temperature $\mathrm{NO}_{x}$ conversion capability of the TWC. The addition of $2500 \mathrm{ppm}$ hydrogen decreased the light-off time and temperature by $19 \mathrm{~s}$ and $20^{\circ} \mathrm{C}$ respectively and increased the conversion rate at $270{ }^{\circ} \mathrm{C}$ by $15 \%$ without having a detrimental effect on the maximum conversion efficiency. Figure $4 \mathrm{~d}$ shows the amount oxygen consumed for the three levels of $\mathrm{H}_{2}$ added, resulting in $50 \%$ of the available $\mathrm{O}_{2}$ being converted at $316{ }^{\circ} \mathrm{C}$, $308{ }^{\circ} \mathrm{C}$ and $299^{\circ} \mathrm{C}$ for $500 \mathrm{ppm}, 1500 \mathrm{ppm}$ and 2500 ppm respectively, in comparison to $325^{\circ} \mathrm{C}$ without additional hydrogen in the exhaust.

Figure 4 e shows the hydrogen levels after engine start-up pre- and post-TWC plotted for 400 seconds, including the pre-TWC temperature for an easier comparison to the other available conversion rates in Figure $4 \mathrm{a}$-d. For all $\mathrm{H}_{2}$ addition levels, and without, it can be seen that hydrogen reached almost complete conversion between 100 and 120 seconds after engine 
start. Figure $4 \mathrm{e}$ indicates that prior to the light-off of the pollutant conversion reactions, which occur after more than 100 seconds without $\mathrm{H}_{2}$ added, significantly higher amounts of $\mathrm{H}_{2}$ can be oxidised over the TWC, which is in agreement with the $\mathrm{O}_{2}$ conversion shown in Figure $4 \mathrm{~d}$. However, an interesting observation in Figure $4 \mathrm{e}$ is that despite the high reactivity of hydrogen, when additional hydrogen was added to the exhaust, the post-converter levels started to increase again after reaching this minimum before stabilising after roughly 400 seconds.

From Figure $4 \mathrm{a}$ and $\mathrm{b}$, it can be seen that different lowlevels of hydrogen added to the exhaust showed a reduction in the light-off temperature for $\mathrm{CO}$ and THC oxidation over a $\mathrm{Pd} / \mathrm{Rh} / \mathrm{Pt}$-doped TWC. A more detailed investigation into the actual surface activities in a TWC washcoat would be necessary to draw conclusions about any potential relation of this observation to trends previously reported in oxygenrich exhaust environments [13], [42], where small levels of $\mathrm{H}_{2}$ resulted in the most significant effect on the light-off performance of oxidation catalysts and was not solely attributable to the exothermic gain through $\mathrm{H}_{2}$ oxidation. However, the positive effect of $\mathrm{H}_{2}$ addition on light-off time and temperature could potentially be beneficial in reaching TWC light-off quicker after engine start [12], [43]. (a)

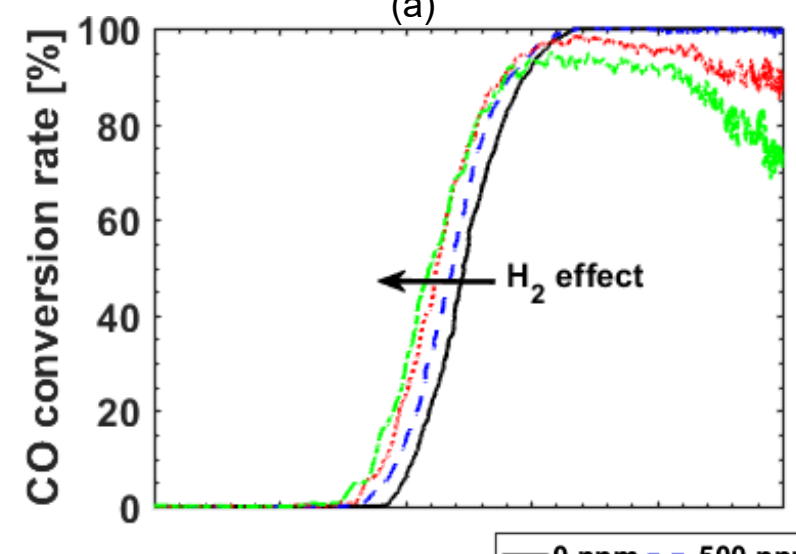

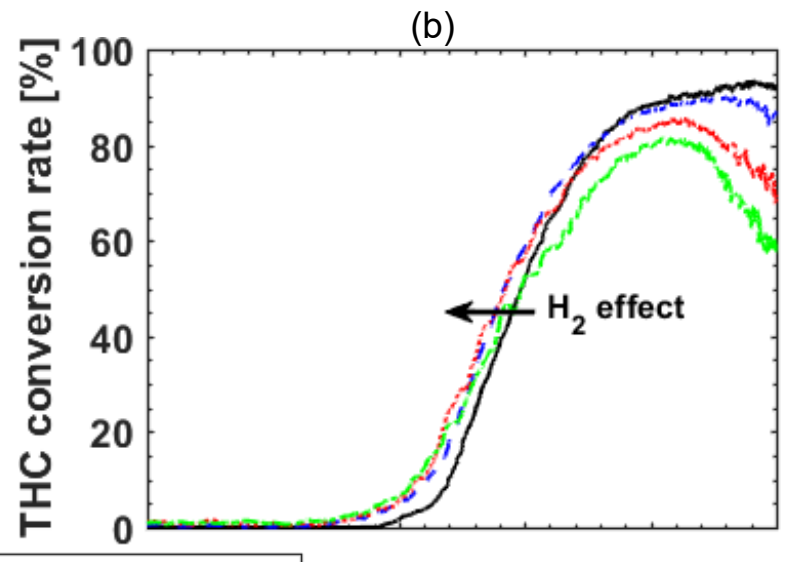

(c)

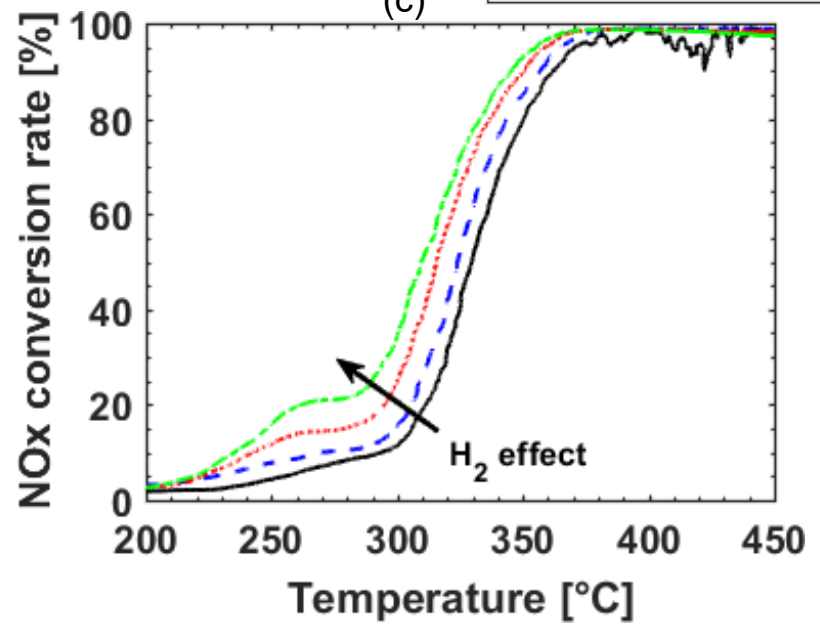

(e)
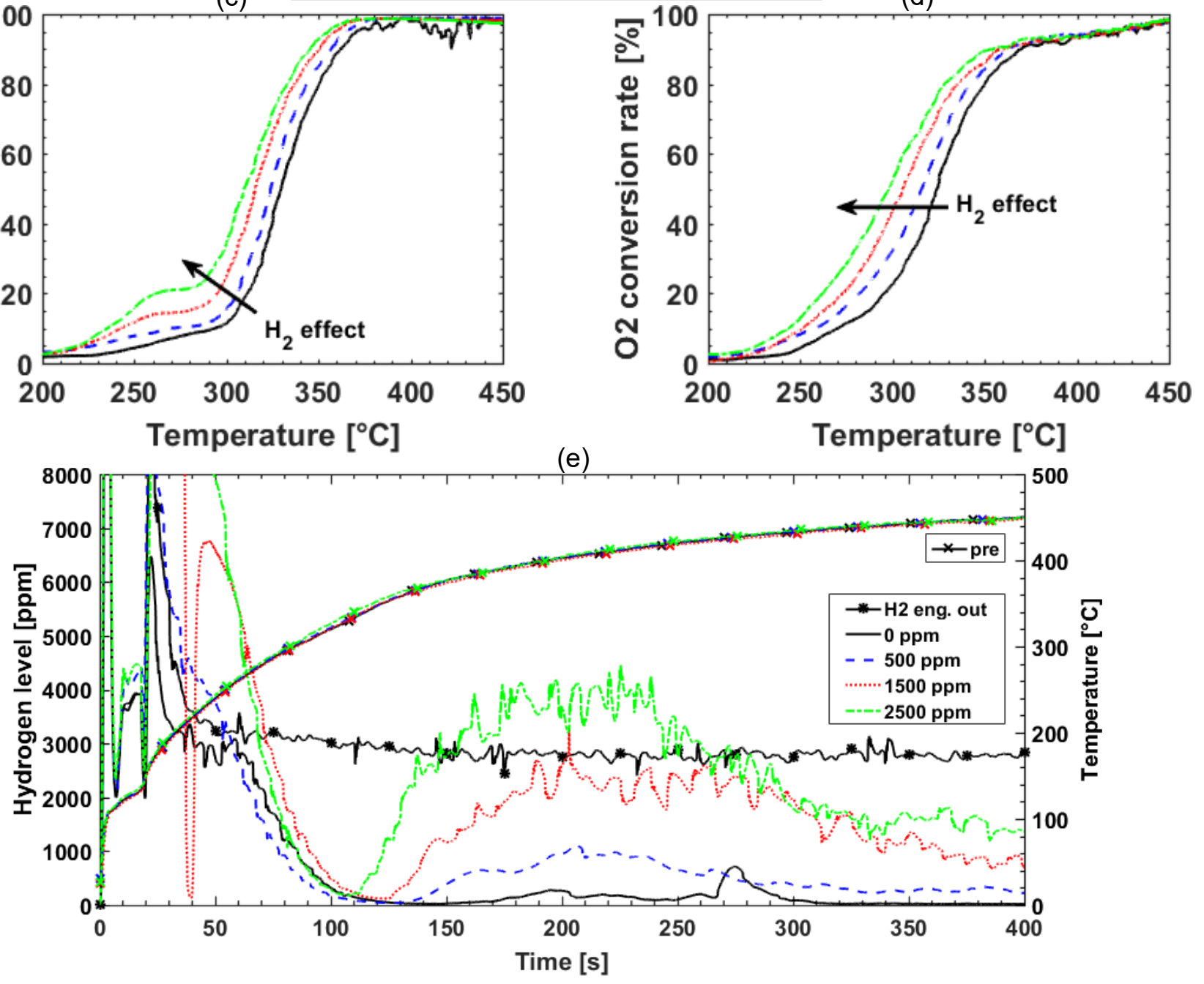

Figure 4: Light-off conversion rates of (a) CO, (b) THC, (c) NOx and (d) $\mathrm{O}_{2}$ plotted against inlet TWC temperature for different levels of $\mathrm{H}_{2}$ addition and (e) hydrogen levels pre-/ post TWC and pre-TWC temperature plotted over time after engine start with the engine operated on RGL only 
It is tentatively suggested that the significant improvement in $\mathrm{NO}_{x}$ reduction (Figure $4 \mathrm{c}$ ) is potentially caused by $\mathrm{H}_{2}$ as a direct reductant of $\mathrm{NO}_{x}$, as well as indirectly through increased competition for the available oxygen and thus promoting reduction of $\mathrm{NO}_{x}$ by $\mathrm{CO}$ and THC. Additional surface studies would be necessary to investigate potential $\mathrm{H}_{2}$ addition effects which were observed in oxygen-rich aftertreatment devices, such as surface-adsorbed hydrogen leading to an acceleration in dissociative adsorption of NO causing the improving lowtemperature conversion rates [20], [21]. In a TWC environment, the observed low-temperature improvements might be the results of the $\mathrm{NO}_{x}$ conversion to the more harmful $\mathrm{N}_{2} \mathrm{O}$ and $\mathrm{NH}_{3}$, instead of $\mathrm{N}_{2}$, which has been reported over PGM TWC, especially in rich low-temperature environments around $250{ }^{\circ} \mathrm{C}$ and which could be caused by hydrogen addition as performed in this study [44]. Furthermore, it is also interesting to note in Figure $4 \mathrm{e}$ that maximum values of $\mathrm{H}_{2}$ measured downstream of the converter exceeded the amounts added which might be attributed to $\mathrm{H}_{2}$ production by the Water-Gas shift (WGS) inside the TWC.

Further to the constant measurement of exhaust lambda, as described in the engine set-up, a value of lambda upstream of the TWC was calculated on the basis of the measured emissions and know $\mathrm{H}_{2}$ addition levels. As might be expected, in all cases the addition of $\mathrm{H}_{2}$ resulted in a shift in lambda towards rich regime; albeit by less than $0.01 \lambda$. Two equations were used to compare the shift in recalculated lambda upstream of the TWC, adapted from Germann et al. [45], and Brinkmeier [46]:

$$
\begin{gathered}
\lambda=\frac{2 y_{\mathrm{O}_{2}}+2 y_{\mathrm{CO}_{2}}+y_{\mathrm{H}_{2} \mathrm{O}}+y_{\mathrm{CO}}+y_{\mathrm{NO}_{x}}}{2 y_{\mathrm{CO}}+y_{\mathrm{H}_{2}}+4 y_{\mathrm{THC}}+2 y_{\mathrm{CO}_{2}}+y_{\mathrm{H}_{2} \mathrm{O}}} \\
\lambda=\frac{y_{\mathrm{O}_{2, \text { air }}}}{4+x} \cdot \frac{4 Y+x\left(2-2 y_{\mathrm{H}_{2}}-2 y_{\mathrm{CO}}-4 y_{\mathrm{THC}}+2 y_{\mathrm{O}_{2}}+y_{\mathrm{NO}}\right)}{y_{\mathrm{H}_{2}}+y_{\mathrm{CO}}+4 y_{\mathrm{THC}}-2 y_{\mathrm{O}_{2}}-y_{\mathrm{NO}}+y_{O_{2, a i r}} \cdot Y} \\
\text { with } Y=2-y_{\mathrm{H}_{2}}-y_{\mathrm{CO}}+y_{\mathrm{THC}}
\end{gathered}
$$

where $y_{Z}$ denotes the concentration of the individual species $Z$ and $x$ represents the $\mathrm{H}: C$ ratio of the fuel. The changes in lambda post $\mathrm{H}_{2}$ addition are summarised in Table 5 showing the calculated change of lambda with the addition of hydrogen in relation to the lambda value without hydrogen.

Table 5: Recalculated of lambda changes through added $\mathrm{H}_{2}$

\begin{tabular}{|cccc|}
\hline & $500 \mathrm{ppm}$ & $1500 \mathrm{ppm}$ & $2500 \mathrm{ppm}$ \\
\hline Equ. (1) & $0.12 \%$ & $0.24 \%$ & $0.59 \%$ \\
Equ. (2) & $0.14 \%$ & $0.40 \%$ & $0.67 \%$ \\
\hline
\end{tabular}

The values in Table 5 show that the shift of lambda is below $1 \%$, even with 2500 ppm of $\mathrm{H}_{2}$ added. The change would not be enough to, for example, shift the lambda perturbation to a constantly rich environment and cause a reduction in efficiency through prolonged depletion of the oxygen storage.

\section{PARTICULATE EMISSIONS}

Figure 5 shows the total particulate number (PN) (a) and particulate mass (PM) (b) pre- and post-TWC for reference gasoline over the first 300 seconds after engine start, with the error bars present showing the standard deviation pre-TWC and each data point shown is the average measured over the preceding 10 seconds.
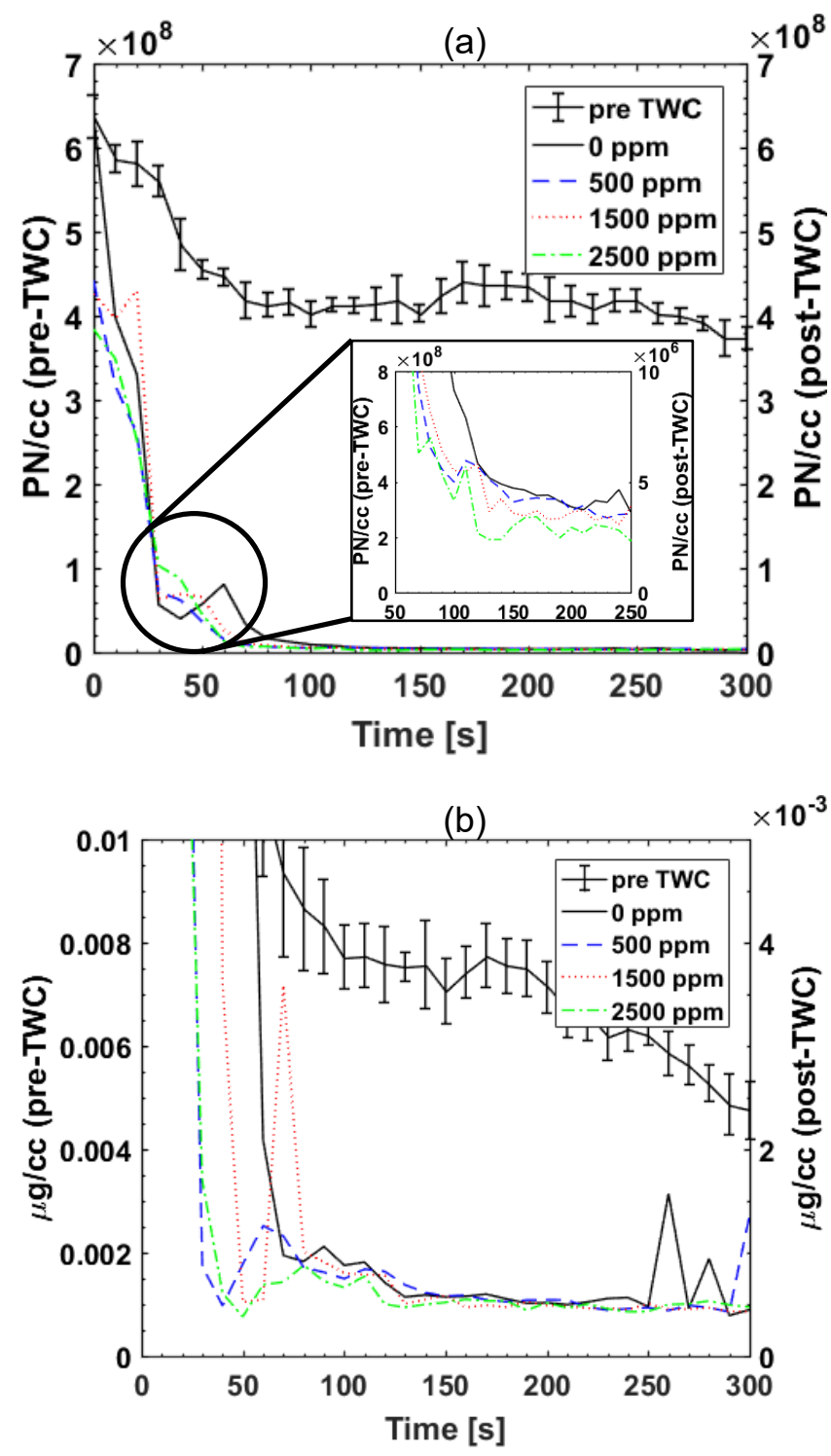

Figure 5: (a) Particulate number and (b) particulate mass emissions pre-/ post-TWC for different levels of $\mathrm{H}_{2}$ addition

It can be observed in Figure 5 a that the engine-out PN levels stabilised at roughly $4.0 \times 10^{8} / \mathrm{cc} 300$ seconds after engine start. The post-TWC values in Figure 5 a show a high efficiency of the TWC in reducing PN, decreasing the engine out levels by more than two orders of magnitudes to below $4.0 \times 10^{6} / \mathrm{cc}$, and increasing levels of $\mathrm{H}_{2}$ addition resulted in a faster decrease in PN post-TWC. The highest level of $\mathrm{H}_{2}$ addition (2500 ppm) reduced the time required to reach minimum $\mathrm{PN}$ levels post-TWC relative to lower levels and the absence of $\mathrm{H}_{2}$ addition, but did not achieve greater levels of reduction. These reduction levels over a commercial TWC indicated similar trends as previously reported in the literature [4], [47]-[49], which observed a high efficiency of trapping and oxidising nucleation mode particles in a TWC. 
The engine out particulate mass (PM) shown in Figure $5 \mathrm{~b}$ stabilised after $300 \mathrm{~s}$ of engine run time at roughly $0.005 \mu \mathrm{g} / \mathrm{cc}$, and it can be observed that levels of PM were reduced to below $1.0 \times 10^{-3} \mathrm{\mu g} / \mathrm{cc}$ post-TWC. With the majority of PM attributable to larger accumulation mode particulates, the PM reduction across the TWC for RGL was not as significant as the effect on the PN (Figure $5 \mathrm{a}$ ), pointing towards a more pronounced effect of the TWC on oxidising and trapping nucleation mode particles [4], [47]-[49]. As with the particulate number, increasing levels of $\mathrm{H}_{2}$ added to the exhaust stream showed a positive effect in decreasing the time to reach minimum PM levels. This positive effect of hydrogen addition might potentially be attributed to the heat introduced into the converter and increasing rates of particulate oxidation; this advantage with $\mathrm{H}_{2}$ addition would be reduced with increasing brick temperature leading to similar levels of PN and PM reached with and without additional $\mathrm{H}_{2}$ as apparent in Figure $5 \mathrm{a}$ and b. Additionally, it is noteworthy from Figure 5 a that near steady post-TWC PN levels were reached ahead of the gaseous species light-off. Whelan et al. [49] suggested that the conversion of nucleation mode particles in a TWC might start at temperatures below $100{ }^{\circ} \mathrm{C}$, whereas a significant conversion of $\mathrm{CO}, \mathrm{THC}$ and $\mathrm{NO}_{\mathrm{x}}$ was not observed at TWC inlet temperatures lower than $250^{\circ} \mathrm{C}$.
COMPARISON OF EMISSIONS REDUCTION ACROSS THE TWC FOR DIFFERENT FUELS

Figure 6 shows the relative change in catalyst inlet temperature for the consumption of a specific amount of each legislated species for all fuel blends tested, normalised against the RGL temperature. The consumption-based comparison should reduce the bias of varying fuel blend engine-out emissions on the light-off temperature.

In Figure 6, it can be seen that for all of the fuel blends containing a $\mathrm{C}_{2}$-oxygenate a reduction of $0.6 \% \mathrm{CO}$, 600 ppm NO and 1200 ppm THC occurred at a lower exhaust inlet temperature in comparison to RGL. With ETH a decrease of $5^{\circ} \mathrm{C}$ for $\mathrm{CO}, 3^{\circ} \mathrm{C}$ for NOx and $8^{\circ} \mathrm{C}$ for THC was observed. ACA and DEE also showed a temperature decrease for $\mathrm{CO}$ and THC conversion, with $\mathrm{ACA}$ reducing $\mathrm{NO}_{\mathrm{x}}$ at a temperature $6{ }^{\circ} \mathrm{C}$ below reference gasoline. With the oxygenated $\mathrm{C}_{4}$-group molecules BTN, BTA, BUO and MTBE a less significant effect was observed. BTN performed similarly to gasoline in regards to $\mathrm{CO}$ and $\mathrm{NO}_{x}$ conversion and had a $3{ }^{\circ} \mathrm{C}$ decrease in converting THC. The MTBE fuel blend was the only fuel blend containing a $\mathrm{C}_{4}$-oxygenate to show a decreased conversion temperature relative to gasoline for all three emission species (Figure 6).

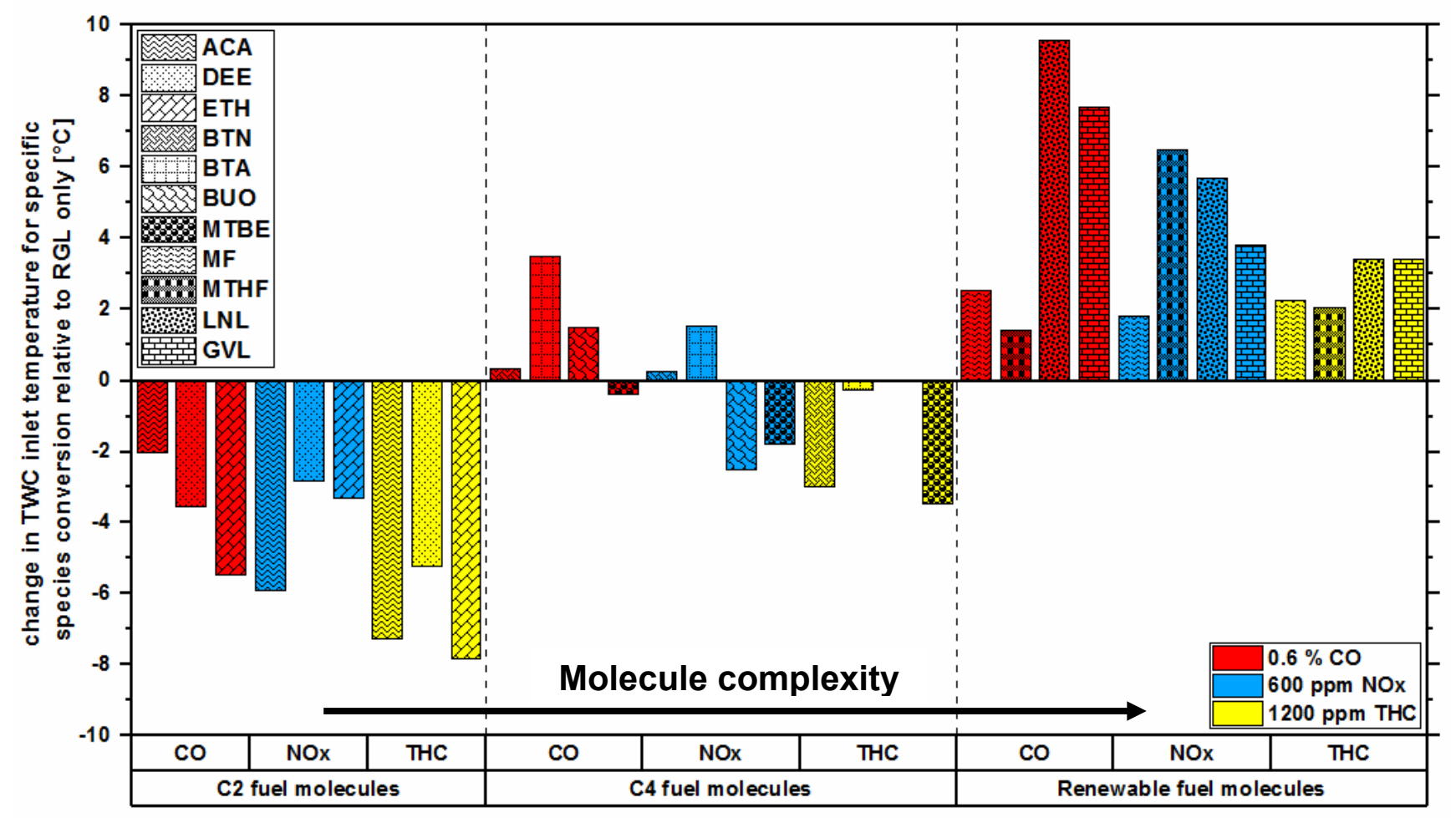

Figure 6: Relative inlet TWC temperature change to consume a specific amount of emission species for all tested fuel blends

The setup used did not incorporate any further speciation of the exhaust gas to gain a more detailed picture of present hydrocarbon species. However, previous studies have observed the use of oxygenated fuel blends to result in increased exhaust levels of oxygenated molecules, present either as unburned fuel components or closely related molecules [50], [51]. The speciation of unregulated gaseous emissions of an engine operated with different levels of ethanol blended in gasoline resulted in increased amounts of ethanol and aldehyde species in the exhaust [52]. Furthermore, Bogarra et al. [4] formulated the following 
order for the preferential conversion of unregulated species over a TWC as follows (from first to last): alcohol > aldehydes $>$ aromatics $>$ alkenes $>$ alkanes, which correlates with the conversion efficiency results shown Figure 6.

The alcohols in the $\mathrm{C}_{2}$ - and $\mathrm{C}_{4}$-groups performed similar to or better than the other molecules of the same respective carbon chain length. Boot et al. [53] stated the extraction of the $\mathrm{OH}$-group, attached to the paraffinic structure of alcohol, and the weakening of the adjacent $\mathrm{C}$ bonds as one of the first steps in alcohol combustion. This might lead to an increased number of hydroxyl radicals, which have been suggested to be crucial in oxidation reactions on noble metal-doped catalytic converters [54]. Furthermore, ETH is reported to be easier converted over a TWC than other oxygenated species including for example aldehydes [4]. The best overall performance for the group of renewable derived oxygenate molecules was observed with MF and MTHF, which had been reported to have an exhaust composition not drastically different from commercial 95 octane gasoline [55]-[57], however, all of the fuel blends (MF, MTHF, LNL, GVL) showed an increase in exhaust temperature to convert the specific amount of exhaust species in comparison to RGL. The most significant increase in temperature was observed with LNL, which increased the temperature for $0.6 \% \mathrm{CO}$ consumption by almost $10{ }^{\circ} \mathrm{C}$ and MF displayed the least significant increase for the three species. A considerably higher molecular mass of the molecules (Table 4) in the renewable grouping, specifically in the case of GVL and LNL, might have caused reduced diffusivity and less access to the active sites in the washcoat. In contrast to GVL and LNL, the MF and MTHF blends showed no explicit trend of increasing inlet TWC temperature when converting $\mathrm{CO}, \mathrm{THC}$ and $\mathrm{NO}_{x}$, in comparison to RGL.

The temperature trends observed in Figure 6 suggest a correlation between conversion efficiency and molecule complexity or chain length of the oxygenated blending molecule used. Shorter and less complex $\mathrm{C}_{2-}$ chain molecules showed a reduction in pre-catalyst temperature and with increasing complexity and chain length of the $\mathrm{C}_{4}$-chain molecule the effect decreased. The cyclic structure of MF, MTHF and GVL, as well as the long paraffinic backbone of $\mathrm{LNL}$, resulted in a reversed effect and increased the inlet TWC temperature. This would correlate with suggestions in the theory of oxygenated fuel combustion, where larger, more complex molecules result in a reduced reactivity of the main molecule structure, which might extend the process of breaking down those hydrocarbons on the catalytic surface [30], [53]. Furthermore, the THC conversion showed overall the highest decrease and lowest increase in the required inlet temperature relative to $\mathrm{CO}$ and $\mathrm{NO}_{\mathrm{x}}$ conversion, for the $\mathrm{C}_{2}$ and $\mathrm{C}_{4}$ molecules, and renewable fuel molecules respectively (Figure 6). This might be further attributed to the fact that the overall $\mathrm{H} / \mathrm{C}$ ratio of the fuel blend is reduced by the oxygenated fuel molecules, possibly resulting in a tendency of overall shorter chain hydrocarbons in the exhaust stream and therefore to a faster conversion. It is tentatively suggested that relative to the THC oxidation, CO oxidation over the TWC may still be mainly dependent on the amount of available active sites and adatomic oxygen, and less on the availability of oxygenated hydrocarbon molecules. The conversion of $\mathrm{NO}_{x}$ to $\mathrm{N}_{2}$ mainly relies on $\mathrm{CO}$ and $\mathrm{THC}$ as reducing agents, and so shorter hydrocarbon chains might further benefit $\mathrm{NO}_{x}$ conversion by a reduced number of necessary reaction steps.

\section{EFFECT OF HYDROGEN ADDITION ON TWC PERFORMANCE WHEN USING DIFFERENT OXYGENATED FUEL BLENDS}

The results of operating the engine with varying oxygenated fuel blends and the addition of hydrogen in different levels are summarised qualitatively in Table 6 , showing the overall impact of increasing $\mathrm{H}_{2}$ with the different groups of oxygenated fuel blends tested.

Table 6: Summary of the relative change in inlet TWC temperature required to consume a specific amount of emission species with increasing levels of $\mathrm{H}_{2}$ added for the three groups of tested fuel blends and the overall effects ranging from -- = strong negative to $++=$ strong positive impact.

\begin{tabular}{|cccc|}
\hline & $\mathrm{CO}$ & $\mathrm{THC}$ & $\mathrm{NO}_{\mathrm{x}}$ \\
\hline $\mathrm{C}_{2}$ & - & $=$ & ++ \\
$\mathrm{C}_{4}$ & -- & - & + \\
Renewable & -- & -- & - \\
\hline
\end{tabular}

It can be seen in Table 6 that $\mathrm{CO}$ oxidation was the conversion reaction most affected by higher fuel molecule complexity and increasing addition $\mathrm{H}_{2}$ levels, with an increase in necessary temperatures with longer oxygenated fuel molecules in the fuel blend and higher levels of $\mathrm{H}_{2}$ added to the exhaust. THC oxidation showed similar trends seen with $\mathrm{CO}$ for increasing levels of $\mathrm{H}_{2}$ but at a slightly lower magnitude for all tested oxygenated fuel blends, except the use of BTN which resulted in a decreasing temperature with increasing $\mathrm{H}_{2}$ levels. The $\mathrm{NO}_{x}$ reduction was the conversion reaction least negatively affected by increasing $\mathrm{H}_{2}$ levels, as discussed in the context of Figure $4 \mathrm{c}$, both direct and indirect reduction of $\mathrm{NO}_{x}$ by $\mathrm{H}_{2}$ might be expected, with only the latter route likely to be influenced by the composition of THC present.

Overall, the two alcohol blends, ETH and BTN showed the most significant decrease in inlet temperature (Figure 6). In comparison to $\mathrm{RGL}$ and $\mathrm{no}_{2}$ added, BTN reduced the temperature for the conversion of $\mathrm{CO}$, $\mathrm{THC}$ and $\mathrm{NO}_{x}\left(1500 \mathrm{ppm} \mathrm{H}_{2}\right.$ added) by $3^{\circ} \mathrm{C}, 10^{\circ} \mathrm{C}$ and $7^{\circ} \mathrm{C}$ respectively. The TWC showed similar trends for PN/ PM with all tested oxygenated fuel blends and hydrogen levels as discussed in Figure 5 with reference gasoline only. However, increased levels of PN were observed for GVL and LNL post-TWC, potentially due to the presence of increased levels of accumulation mode particles, despite similar engine out total PN levels; it is tentatively suggested therefore that these larger molecules would thus require a greater number of reaction steps to oxidise, in comparison to particulates emitted by the other fuel blends. The elevated post-converter PN levels for GVL and LNL might suggest an additional explanation for 
the decrease in $\mathrm{CO}$ and THC oxidation performance for both fuel blends as if the particles persist through the converter it may mutually reduce diffusivity and accessibility to the active sites and therefore decrease conversion efficiency.

\section{CONCLUSIONS}

The light-off performance of a TWC with different hydrogen levels added to the exhaust stream of a GDI engine was investigated, with the engine operated on fossil gasoline and eleven different potential oxygenated fuel blends. Legislated gaseous and solid species, as well as temperature, oxygen and hydrogen trends, were measured to gain a deeper understanding of the effects of $\mathrm{H}_{2}$ addition and oxygenated fuel blends on a TWC. The following conclusions can be drawn from the results:

1. Hydrogen showed a beneficial effect on the lightoff performance of a TWC, with levels below 1500 ppm of $\mathrm{H}_{2}$ added resulting in the most significant concurrent decrease in light-off temperature for $\mathrm{CO}, \mathrm{THC}$ and $\mathrm{NO}_{x}$ conversion.

2. The actual exhaust stoichiometry entering the TWC after the addition of 2500 ppm H2 did result in a large enough shift to move the perturbation into a permanently rich environment.

3. Increasing levels of $\mathrm{H}_{2}$ added to the exhaust gases increased $\mathrm{H}_{2}$ levels measured post the TWC, after conversion of $\mathrm{CO}$ and THC commenced, suggesting competition for the available oxygen and potentially active sites with preferential oxidation of $\mathrm{CO}$ and $\mathrm{THC}$ ahead of $\mathrm{H}_{2}$.

4. Without $\mathrm{H}_{2}$ addition, the use of $\mathrm{C}_{2}$ oxygenated fuel blends resulted in a decrease in temperature necessary for conversion of gaseous pollutant species, whereas $\mathrm{C}_{4-}$ and renewable oxygenated fuel blends either did not show an apparent effect or increased the necessary conversion temperature.

5. A reduced conversion temperature for the ETH and BTL blends with increasing levels of $\mathrm{H}_{2}$ up to $1500 \mathrm{ppm}$ was observed, and was attributed to the potentially increased amount of intermediate molecules favourable to oxidation with the use of alcohol fuel blends.

6. Fuel composition was observed to be of greater significance in determining the levels of $\mathrm{PN}$ and PM reduction across the TWC than the addition of $\mathrm{H}_{2}$. Furthermore, more significant reductions in PN relative to PM across the TWC were observed, attributable to the greater capability of the TWC to trap and oxidise small nucleation mode particles.

\section{REFERENCES}

[1] C. Hagelüken, Autoabgaskatalysatoren: Grundlagen - Herstellung - Entwicklung Recycling - Ökologie. Expert-Verlag GmbH, 2016.

[2] T. Johnson and A. Joshi, "Review of Vehicle Engine Efficiency and Emissions," 2017.

[3] K. Winkler, W. Müller, and K. Reif, "Abgasnachbehandlung für Ottomotoren," in Abgastechnik für Verbrennungsmotoren, $\mathrm{K}$. Reif, Ed. Wiesbaden: Springer Fachmedien Wiesbaden, 2015, pp. 80-111.

[4] M. Bogarra, J. M. Herreros, C. Hergueta, A. Tsolakis, A. P. E. York, and P. J. Millington, "Influence of Three-Way Catalyst on Gaseous and Particulate Matter Emissions During Gasoline Direct Injection Engine Cold-start," Johnson Matthey Technol. Rev., vol. 61, no. 4, pp. 329-341, Oct. 2017.

[5] T. Johnson and A. Joshi, "Review of Vehicle Engine Efficiency and Emissions," 2018.

[6] Y. Kong, S. Crane, P. Patel, and B. Taylor, "NOx Trap Regeneration with an On-Board Hydrogen Generation Device," 2004.

[7] S. Sitshebo, A. Tsolakis, and K. Theinnoi, "Promoting hydrocarbon-SCR of NOx in diesel engine exhaust by hydrogen and fuel reforming," Int. J. Hydrogen Energy, vol. 34, no. 18, pp. 7842-7850, Sep. 2009.

[8] D. Fennell, J. Herreros, and A. Tsolakis, "Improving gasoline direct injection (GDI) engine efficiency and emissions with hydrogen from exhaust gas fuel reforming," Int. $J$. Hydrogen Energy, vol. 39, no. 10, pp. 51535162, 2014.

[9] K. Ashida, H. Maeda, T. Araki, M. Hoshino, K. Hiraya, T. Izumi, and M. Yasuoka, "Study of an On-board Fuel Reformer and Hydrogen-Added EGR Combustion in a Gasoline Engine," SAE Int. J. Fuels Lubr., vol. 8, no. 2, pp. 2015-010902, Apr. 2015.

[10] R. Gukelberger, G. J. Bartley, J. Gingrich, T. Alger, S. Almaraz, J. Buckingham, and C. Henry, "Water-Gas-Shift Catalyst Development and Optimization for a D-EGR $®$ Engine," 2015.

[11] G. Mazzolai, "Perspectives and challenges for solid state hydrogen storage in automotive applications," Recent Patents Mater. Sci., vol. 5, no. 2, pp. 137-148, 2012.

[12] M. J. Heimrich and C. C. Andrews, "On-Board Hydrogen Generation for Rapid Catalyst LightOff," 2000.

[13] S. Salomons, M. Votsmeier, R. E. Hayes, A. Drochner, H. Vogel, and J. Gieshof, "CO and $\mathrm{H} 2$ oxidation on a platinum monolith diesel oxidation catalyst," Catal. Today, vol. 117, no. 4, pp. 491-497, Oct. 2006.

[14] J. M. Herreros, S. S. Gill, I. Lefort, A. Tsolakis, P. Millington, and E. Moss, "Enhancing the low 
temperature oxidation performance over a $\mathrm{Pt}$ and a Pt-Pd diesel oxidation catalyst," Appl. Catal. B Environ., vol. 147, pp. 835-841, Apr. 2014.

[15] N. A. Sadokhina, A. V. Bukhtiyarov, A. I. Mytareva, R. I. Kvon, V. I. Bukhtiyarov, and A. Y. Stakheev, "Mechanism of H2-promoted oxidation of nitrogen monoxide over Ag/AI2O3," Mendeleev Commun., vol. 21, no. 5, pp. 274276, Sep. 2011.

[16] C. L. DiMaggio, G. B. Fisher, K. M. Rahmoeller, and M. Sellnau, "Dual SCR Aftertreatment for Lean NOx Reduction," SAE Int. J. Fuels Lubr., vol. 2, no. 1, pp. 2009-01-0277, Apr. 2009.

[17] K. chul Park, S. Song, and K. min Chun, "Low Temperature Active Regeneration of Soot Using Hydrogen in a Multi-Channel Catalyzed DPF," 2010.

[18] S. Salomons, R. E. Hayes, and M. Votsmeier, "The promotion of carbon monoxide oxidation by hydrogen on supported platinum catalyst," Appl. Catal. A Gen., vol. 352, no. 1-2, pp. 2734, Jan. 2009.

[19] M. Sun, E. B. Croiset, R. R. Hudgins, P. L. Silveston, and M. Menzinger, "Steady-State Multiplicity and Superadiabatic Extinction Waves in the Oxidation of $\mathrm{CO} / \mathrm{H} 2$ Mixtures over a Pt/Al 2 O 3 -Coated Monolith," Ind. Eng. Chem. Res., vol. 42, no. 1, pp. 37-45, Jan. 2003.

[20] R. Burch and M. D. Coleman, "An investigation of the $\mathrm{NO} / \mathrm{H} 2 / \mathrm{O} 2$ reaction on noble-metal catalysts at low temperatures under lean-burn conditions," Appl. Catal. B Environ., vol. 23, no. 2-3, pp. 115-121, 1999.

[21] R. Burch and M. D. Coleman, "An Investigation of Promoter Effects in the Reduction of NO by H2 under Lean-Burn Conditions," J. Catal., vol. 208, no. 2, pp. 435-447, Jun. 2002.

[22] S. Satokawa, J. Shibata, K. Shimizu, A. Satsuma, and T. Hattori, "Promotion effect of $\mathrm{H} 2$ on the low temperature activity of the selective reduction of $\mathrm{NO}$ by light hydrocarbons over Ag/Al2O3," Appl. Catal. B Environ., vol. 42, no. 2, pp. 179-186, May 2003.

European

Union,

COMMISSION REGULATION (EU) 2016/427 of 10 March 2016 amending Regulation (EC) No 692/2008 as regards emissions from light passenger and commercial vehicles (Euro 6). European Union: eur-lex.europe.eu, 2016, pp. 1-98.

[24] ICCT, "Final recast Renewable Energy Directive for 2021-2030 in the European Union," 2018.

[25] W. Leitner, J. Klankermayer, S. Pischinger, H. Pitsch, and K. Kohse-Höinghaus, "Advanced Biofuels and Beyond: Chemistry Solutions for Propulsion and Production," Angew. Chemie Int. Ed., vol. 56, no. 20, pp. 5412-5452, May 2017.

[26] R. D. Perlack, L. L. Wright, A. F. Turhollow, R. L. Graham, B. J. Stoke, and D. C. Erbach,
"Biomass as Feedstock for Bioenergy and Bioproducts Industry: The Technical Feasiblity of a Billion-Ton Annnual Supply," 2005.

[27] R. L. McCormick, M. A. Ratcliff, E. Christensen, L. Fouts, J. Luecke, G. M. Chupka, J. Yanowitz, M. Tian, and M. Boot, "Properties of Oxygenates Found in Upgraded Biomass Pyrolysis Oil as Components of Spark and Compression Ignition Engine Fuels," Energy \& Fuels, vol. 29, no. 4, pp. 2453-2461, Apr. 2015.

[28] A. Sudholt, R. Tripathi, D. Mayer, P.-A. Glaude, F. Battin-Leclerc, and H. Pitsch, "The oxidation of the novel lignocellulosic biofuel $\mathrm{Y}$ valerolactone in a low pressure flame," Proc. Combust. Inst., vol. 36, no. 1, pp. 577-585, 2017.

[29] J. Yanowitz, E. Christensen, and R. L. McCormick, "Utilization of Renewable Oxygenates as Gasoline Blending Components," Golden, CO (United States), Aug. 2011.

[30] S. M. Sarathy, P. Oßwald, N. Hansen, and K. Kohse-Höinghaus, "Alcohol combustion chemistry," Prog. Energy Combust. Sci., vol. 44, pp. 40-102, Oct. 2014.

[31] I. Schifter, U. González, L. Díaz, C. GonzálezMacías, and I. Mejía-Centeno, "Experimental and vehicle (on road) test investigations of spark-ignited engine performance and emissions using high concentration of MTBE as oxygenated additive," Fuel, vol. 187, no. 11, pp. 276-284, Jan. 2017.

[32] M. A. Fayad, A. Tsolakis, D. FernándezRodríguez, J. M. Herreros, F. J. Martos, and M. Lapuerta, "Manipulating modern diesel engine particulate emission characteristics through butanol fuel blending and fuel injection strategies for efficient diesel oxidation catalysts," Appl. Energy, vol. 190, pp. 490-500, Mar. 2017.

[33] M. A. Fayad, D. Fernández-Rodríguez, J. M. Herreros, M. Lapuerta, and A. Tsolakis, "Interactions between aftertreatment systems architecture and combustion of oxygenated fuels for improved low temperature catalysts activity," Fuel, vol. 229, no. October 2017, pp. 189-197, Oct. 2018.

[34] J. M. Herreros, P. George, M. Umar, and A. Tsolakis, "Enhancing selective catalytic reduction of NOx with alternative reactants/promoters," Chem. Eng. J., vol. 252, pp. 47-54, Sep. 2014.

[35] G. A. Ingram, G. Surnilla, and F. M. Co, "On-line Oxygen Storage Capacity Estimation of a Catalyst," Engineering, vol. 2003, no. 724, 2003.

[36] J. C. Peyton Jones and R. A. Jackson, "Potential and Pitfalls in the Use of dual exhaust gas oxygen sensors for three-way catalyst monitoring and control," Proc. Inst. Mech. Eng. Part D J. Automob. Eng., vol. 217, no. 6, pp. 475-488, Jun. 2003. 
[37] B. Geringer, J. Spreitzer, M. Mayer, and C. Martin, Meta-analysis for an E20/25 technical development study - Task 2: Meta-analysis of E20/25 trial reports and associated data. 2014.

[38] O. Costenoble and M. A. Fortunato, "Organization and implementation of a trial on energy and environmental performance of E20 capable cars," 2014.

[39] EUROPEAN COMMISSION, "Horizon 2020 Work Programme 2018-2020 - 10. Secure, clean and efficient energy," 2018.

[40] EUROPEAN COMMISSION, "Regulated emissions of a Euro 5 passenger car measured over different driving cycles," p. 23, 2010.

[41] G. Moresche, "caesur - computer aided engineering sur," 2016. [Online]. Available: http://caesur.spdns.de/. [Accessed: 23-Nov2016].

[42] S. R. Katare and P. M. Laing, "Hydrogen in Diesel Exhaust: Effect on Diesel Oxidation Catalyst Flow Reactor Experiments and Model Predictions," SAE Int. J. Fuels Lubr., vol. 2, no. 1, pp. 605-611, 2009.

[43] P. Marsh, I. Gottberg, K. Thorn, M. Lundgren, F. Acke, and G. Wirmark, "SULEV Emission Technologies for a Five Cylinder N/A Engine," 2000.

[44] C. D. Digiulio, J. A. Pihl, J. E. P. Ii, M. D. Amiridis, and T. J. Toops, "Passive-ammonia selective catalytic reduction (SCR): Understanding $\mathrm{NH} 3$ formation over close-coupled three way catalysts (TWC)," Catal. Today, vol. 231, no. X, pp. 33-45, 2014.

[45] H. Germann, S. Taglaiferri, and H. P. Geering, "Differences in Pre- and Post-Converter Lambda Sensor Characteristics," 1996.

[46] C. Brinkmeier, "Automotive Three-Way Exhaust Aftertreatment under Transient Conditions Measurements, Modeling and Simulation," 2006.

[47] M. A. Costagliola, L. De Simio, S. Iannaccone, and M. V. Prati, "Combustion efficiency and engine out emissions of a S.I. engine fueled with alcohol/gasoline blends," Appl. Energy, vol. 111, pp. 1162-1171, Nov. 2013.

[48] J. Cho, W. Si, W. Jang, D. Jin, C.-L. Myung, and S. Park, "Impact of intermediate ethanol blends on particulate matter emission from a spark ignition direct injection (SIDI) engine," Appl. Energy, vol. 160, pp. 592-602, Dec. 2015.

[49] I. Whelan, D. Timoney, W. Smith, and S. Samuel, "The Effect of a Three-Way Catalytic Converter on Particulate Matter from a Gasoline Direct-Injection Engine During ColdStart," SAE Int. J. Engines, vol. 6, no. 2, pp. 2013-01-1305, Apr. 2013.

[50] T. Wallner, "Correlation Between Speciated Hydrocarbon Emissions and Flame Ionization Detector Response for Gasoline/Alcohol Blends," J. Eng. Gas Turbines Power, vol. 133, no. 8, p. 082801, 2011.

[51] R. Suarez-Bertoa, A. A. Zardini, H. Keuken, and C. Astorga, "Impact of ethanol containing gasoline blends on emissions from a flex-fuel vehicle tested over the Worldwide Harmonized Light duty Test Cycle (WLTC)," Fuel, vol. 143, pp. 173-182, Mar. 2015.

[52] D. Jin, K. Choi, C.-L. Myung, Y. Lim, J. Lee, and S. Park, "The impact of various ethanolgasoline blends on particulates and unregulated gaseous emissions characteristics from a spark ignition direct injection (SIDI) passenger vehicle," Fuel, vol. 209, no. August, pp. 702-712, Dec. 2017.

[53] M. D. Boot, M. Tian, E. J. M. Hensen, and S. Mani Sarathy, "Impact of fuel molecular structure on auto-ignition behavior - Design rules for future high performance gasolines," Prog. Energy Combust. Sci., vol. 60, pp. 1-25, May 2017.

[54] A. B. Mhadeshwar and D. G. Vlachos, "Is the water-gas shift reaction on Pt simple?," Catal. Today, vol. 105, no. 1, pp. 162-172, Jul. 2005.

[55] M. Thewes, M. Muether, S. Pischinger, M. Budde, A. Brunn, A. Sehr, P. Adomeit, and J. Klankermayer, "Analysis of the impact of 2methylfuran on mixture formation and combustion in a direct-injection spark-ignition engine," Energy and Fuels, vol. 25, no. 12, pp. 5549-5561, 2011.

[56] F. Hoppe, U. Burke, M. Thewes, A. Heufer, F. Kremer, and S. Pischinger, "Tailor-Made Fuels from Biomass: Potentials of 2-butanone and 2methylfuran in direct injection spark ignition engines," Fuel, vol. 167, pp. 106-117, Mar. 2016.

[57] M. Talibi, P. Hellier, and N. Ladommatos, "Investigating the Combustion and Emissions Characteristics of Biomass-Derived Platform Fuels as Gasoline Extenders in a Single Cylinder Spark-Ignition Engine," in SAE Technical Papers, 2017, vol. 2017-Octob.

\section{CONTACT}

Corresponding author:

Viktor Kärcher

viktor.karcher.15@ucl.ac.uk

Tel.: +44 (0) 7951857253

\section{NOMENCLATURE}

$\begin{array}{ll}\text { ACA } & \text { Acetaldehyde } \\ \text { AFR } & \text { Air-to-Fuel ratio } \\ \text { AFR stoich } & \text { Stoichiometric Air-to-Fuel ratio } \\ \text { BMEP } & \text { Brake mean effective pressure } \\ \text { BTA } & \text { Butyraldehyde }\end{array}$




\begin{tabular}{ll} 
BTDC & Before top dead centre \\
BTN & 1-Butanol \\
BUO & 2-Butanone \\
CAD & Crank angle degree \\
CL & Closed-loop \\
CO & Carbon monoxide \\
CO 2 & Carbon dioxide \\
CPSI & Cells per square inch \\
DEE & Diethyl ether \\
DME & Dimethyl ether \\
DOC & Diesel oxidation catalyst \\
ECU & Engine control unit \\
ETH & Ethanol \\
FTP & Federal Test Procedure \\
GHG & Greenhouse gases \\
GSHV & Gas hourly space velocity \\
GVL & Y-valerolactone \\
HMF & 5-hydroxymethyl-2-furaldehyde \\
HRR & Heat release rate \\
ICE & Internal combustion engine \\
IMEP & Indicated mean effective pressure \\
LNL & Linalool \\
MF & 2-methylfuran \\
MTBE & Methyl tert-butyl ether \\
MTHF & 2-methyltetrahydrofuran \\
NOx & Nitrogen oxides \\
PM & Particulate mass \\
PN & Particulate number \\
RED & Renewable energy directive \\
RES & Renewable energy sources \\
RGL & Reference gasoline \\
SCR & Selective catalytic reduction \\
THC & Total hydrocarbon \\
TWC & Three-way catalyst \\
WGS & Water-Gas shift \\
WLTC & Worldwide harmonized Light Duty \\
& Test Cycle \\
\hline
\end{tabular}

